\title{
An Empirical Study on Teacher Talk of Business English Teachers*
}

\author{
MA Jing \\ Qingdao University of Science and Technology, Qingdao, China
}

\begin{abstract}
Business English teachers play a decisive and crucial role in the training of business English talents. Teacher talk as the essential medium in the second language class may directly influence the effectiveness of classroom teaching. However, few studies have been conducted on teacher talk of business English teachers. After reviewing the theories of teacher talk, the paper attempts to explore and reveal the characteristics of teacher talk of business English teachers through quantitative and qualitative studies. Six business English teachers and 46 students in Qingdao University of Science and Technology are chosen as subjects for interviews and questionnaires. Three basic business English courses by different teachers are observed and video recorded for the detailed analysis on teacher talk. Based on the findings of the empirical study, some suggestions and implications are also presented.
\end{abstract}

Keywords: business English teachers, teacher talk, English teaching

\section{Introduction}

With the rapid growth of China's economy and the acceleration of world economic integration, the demand for business English personnel is increasing. Accordingly, the national Ministry of Education approved the establishment of Business English Bachelor of Arts (BA for short) Program in 2007. Until the year of 2013, the number of colleges and universities which have set up business English BA program is 146. According to statistics, the major of Business English has become the top 10 hottest majors in the graduate enrollment. The ever soaring percentage of BEC candidates every year is a good case in point for importance and popularity of business English. However, the business English teachers are appalling scarce in contrast to the huge demand for business English talents. Numan (1991) discusses that the government's policy of rapid development for English leads to the unequal availability of trained and qualified teachers and gap between discipline and pedagogical reality.

Teacher talk as the essential medium in the second language class may directly influence the effectiveness of classroom teaching and reflect the teachers' basic quality as well as the teachers' professional development. Consequently, the research of teacher talk has become a focus of scholars and researchers at home and abroad. Though great achievements have made, it is still far from enough and satisfactory. Through CNKI, most of the published papers focus on teacher talk of English teachers. Teacher talk of business English teachers are rarely studied and explored.

\footnotetext{
* Acknowledgements: This paper is granted by the project "Self-development of Business English Teachers From the Perspective of Multi-disciplinary (14XB27)".

MA Jing, lecturer, M.A., English Department, Qingdao University of Science and Technology.
} 
Therefore, the paper attempts to explore and study the characteristics of teacher talk of business English teachers in classroom teaching in order to find out the problems and weak points of business English teachers. Through the investigation and findings, the author hopes to provide insights and reference to the future study of teacher talk.

\section{Previous Study on Teacher Talk}

Teacher talk is an important medium for teachers to effectively organize and control their classroom activities. Sinclair and Brazil (1982) define teacher talk as the language employed in the classroom for directions, explanations, and guidance to students. Richards (1992) regards teacher talk as the simplified language used by teachers in the classroom teaching. Ellis (1994) explains that teacher talk in classroom teaching is quite different from the talk on other occasions. Teachers make some adjustments to both words and structures for smooth interactions with classroom learners.

Gaies and Henzle pioneered the study on teacher talk in the 1970s, followed by other researchers and scholars. However, the initial research on teacher talk focuses on teachers' teaching language and its classification analysis. Ellis (1994) sums up the characteristics of teacher talk including the amount of discourse, words, speed, structure, context, etc. In the 1990s, with more studies on language acquisition process, some researchers have started the systematic study of effective input of teacher talk and the smooth interaction between teachers and students. Allwright (1991) stresses that teacher talk should create harmonious classroom atmosphere for students to communicate with teachers and classmates freely so as to facilitate language acquisition. In recent years, more and more scholars and researchers in the world have shown greater interest in teacher talk. Ellis (1994) attached great importance to the features of classroom conversation, talk turns in the process of interaction between teachers and students and the strategies that teachers can use to manage and organize class better.

In China, during the past 25 years, teacher talk has gradually become a hot topic in the field of second language acquisition. Through surveying the CNKI database, the author gets 863 articles on teacher talk from 2002 to 2015, in which there are only four articles about teacher talk of business English teachers. The researchers place great emphasis on the study of literature and theory on teacher talk. Few empirical researches came out until 2002. ZHOU Xing and ZHOU Yun (2002) carried out an empirical study on the teacher talk in the student-centered teaching model from the quantitative perspective. HU Xue-wen (2003) analyzed the functions and features of teacher talk and explained that teachers still dominated the classroom teaching. HU Qing-qiu (2004) discussed the arts of questioning, the relationship between questioning form and students' participation in class tasks and activities.

Until now, great achievements have been made in the research of teacher talk both at home and abroad. However, the current research lacks empirical study and studies on teacher talk of business English teachers are greatly insufficient.

\section{Research Design}

\section{Research Questions}

In order to summarize the characteristics of teacher talk in business English teachers and suggest the practical ways to better business English teaching, the present study is designed to answer the following questions: 
(1) How much time does the teacher talk occupy the classroom teaching time?

(2) How much time does the teacher use Chinese in business English class teaching?

(3) What type of questions does the teacher often ask?

(4) How does the teacher give their feedback to students' performance?

\section{Subjects}

Six English teachers in Qingdao University of Science and Technology participate in the experiment and three of them are chosen for observation who are responsible for Business English interpreting, Business English Translation, and Business English Correspondence respectively. These three teachers include one associate professor and two lecturers who have been teaching English for at least 10 years. However, none of them have business background or adequate practical business knowledge.

Forty six English majors (Business-English-oriented) from Qingdao University of Science and Technology are chosen randomly from juniors enrolled in 2013 and seniors enrolled in 2012. All of them have grasped basic English skills but they lack international trade knowledge and are not good at business communications. They are 20 to 21 years old.

\section{Instruments}

The methods of "action research", "experimental study", and "natural inquiry" are frequently employed in the classroom teaching research. The natural inquiry is adopted in this experiment. The author observes and studies the natural occurring activities in the classroom without any intervention so as to describe and understand the features of teacher talk and interaction between the teacher and students. Three other instruments are used in this study: interview, questionnaires, and video recording.

In order to record the whole process of classroom teaching, both observation and video recording are adopted for describing the characteristics of teacher talk. The author personally observes and records the different classes of these three teachers without informing them until the class is about to begin. Thus they can adopt the regular teaching methods without any preparation. Meanwhile, the author just sits at the back of the classroom observing and recording the natural occurring processes of classroom teaching without any intervention. The three teachers' classes are observed and video recorded from April to May 2016.

In order to compensate for the limitations of the video recording, two questionnaires for teachers and students are employed. The questionnaire for teachers comprises 14 items including 10 multiple-choice items and four open questions to disclose their real thoughts on teacher talk so as to find out the current problems in business English teaching. The questionnaire for students consists of 24 multiple-choice items and two open questions to reveal their ideas on teacher talk and likes and dislikes about business English teaching.

All the six business English teachers are interviewed in Chinese respectively without any interruption. The purpose of the interview is to collect more convincing evidence of teacher talk and find out what kind of teacher talk can facilitate learners' input and output in business English classes.

\section{Results and Discussions}

\section{Teacher Talk Time}

The distribution of teacher talk time and student talk time is a big issue in the study of teacher talk. Different 
researchers have got different results from their own study. ZHAO Xiao-hong (1998) describes that teacher talk takes up three-quarter of total time of English classroom teaching. However, ZHOU Xing (2002) shows that teach talk only occupies one-quarter in college English classes. What is the result in business English classes? The author analyzes the transcription of class video recording and questionnaires both for teachers and students. The results are shown in Table 1.

Table 1

Teacher Talk Time

\begin{tabular}{|c|c|c|c|c|c|c|c|}
\hline \multirow{2}{*}{ Course name } & \multicolumn{2}{|c|}{ Teacher talk time $(\mathrm{M})$} & \multicolumn{2}{|c|}{ Student talk time(M) } & \multicolumn{2}{|c|}{ Other activities } & \multirow{2}{*}{$\begin{array}{l}\text { Class time } \\
\mathrm{M}\end{array}$} \\
\hline & $\bar{M}$ & $\%$ & $\mathrm{M}$ & $\%$ & $\bar{M}$ & $\%$ & \\
\hline Business English interpreting & 27 & 54 & 13 & 26 & 10 & 20 & 50 \\
\hline Business English translation & 31 & 62 & 4 & 8 & 15 & 30 & 50 \\
\hline Business English correspondence & 38 & 76 & 5 & 10 & 7 & 14 & 50 \\
\hline Total & 96 & 192 & 22 & 44 & 32 & 64 & 150 \\
\hline Mean & 32 & 64 & 7.3 & 14.67 & 10.67 & 21.33 & 50 \\
\hline
\end{tabular}

Other activities include watching videos, group discussions, doing exercises, etc. Table 1 clearly shows the distribution of teacher talk time and student talk time. The total class time is 150 minutes in which the total amount of teacher talk time is 96 minutes occupying 64 percent averagely. While the total amount of student talk time is only 22 minutes taking up 14.67 percent on average. The data clearly imply that teacher talk still dominates the business English class and students are still playing a passive role in the process of classroom teaching.

The author gets the similar results from the questionnaire for students. More than $80 \%$ students think teacher talk takes up more than $50 \%$ of the total class time. Almost $50 \%$ students admit that student talk is five minutes at most and even $20 \%$ students demonstrate that they are rarely given opportunities to speak.

\section{Language Used in Teacher Talk}

Generally speaking, Chinese is always used in business English class to explain business terms, background knowledge, translation strategies, complex structure, etc., to help students' understand in target language. However, too much Chinese may be harmful for students' target language input and result in learners' bad learning habit. Therefore, whether or not native language should be used in business English class is still a controversial issue.

Table 2

Language Used in Teacher Talk

\begin{tabular}{llll}
\hline Course name & Chinese $(\mathrm{M})$ & Teacher talk time $(\mathrm{M})$ & $\%$ \\
\hline Business English interpreting & 9 & 27 & 33 \\
Business English translation & 18 & 31 & 58 \\
Business English correspondence & 6 & 38 & 16 \\
Total & 33 & 96 & 107 \\
Mean & 11 & 32 & 35.67 \\
\hline
\end{tabular}

As shown in Table 2, the percentages of Chinese used in teacher talk range from $16 \%$ to $58 \%$ partly because of the nature of different business courses. From the questionnaire for students, $21 \%$ students say their teachers 
speak Chinese more than 50\%. When interviewed whether or not Chinese should be used in business English class, all teachers think Chinese should be used to explain business terms considering the non-business background of students.

\section{Type of Questions}

Questioning is one of important tools to test students' understanding and arouse their interests in learning. From Table 3, we can see clearly that displaying questions are more frequently asked than referential questions. It is implied that the main purpose of asking questions is to check whether learners have received what they have learned without considering further and in-depth discussion and exploration in business knowledge. From the questionnaire for students, $52 \%$ of students state that teachers ask more display questions, such as the meanings of business terms, expressions, etc.

Table 3

Type of Questions

\begin{tabular}{|c|c|c|c|c|c|}
\hline \multirow{2}{*}{ Course name } & \multicolumn{2}{|c|}{ Displaying questions } & \multicolumn{2}{|c|}{ Referential questions } & \multirow{2}{*}{ - Total number of questions } \\
\hline & Number & Percentage & Number & Percentage & \\
\hline Business English interpreting & 13 & 81.2 & 3 & 18.8 & 16 \\
\hline Business English translation & 9 & 90 & 1 & 10 & 10 \\
\hline Business English correspondence & 17 & 81 & 4 & 19 & 21 \\
\hline Total & 39 & & 8 & & 47 \\
\hline Mean & 13 & & 2.67 & & 15.67 \\
\hline
\end{tabular}

\section{Teachers' Feedback}

Teacher feedback on learners' performance is one of important aspects of teacher talk. Nunan (1991) indicates that positive teacher feedback can not only make students know whether they finish the task correctly or not but also stimulate their motivation in learning.

In Table 4, teacher feedback is analyzed from positive feedback and negative feedback. Meanwhile, positive feedback is illustrated from simple feedback (yes, correct, good job, excellent, etc.) and comment. While negative feedback is described from direct negative feedback (direct correction, sorry, you got a wrong answer, etc.) and indirect negative feedback (asking another student to answer, asking the student to self-repair, etc.). From Table 4, it can be clearly found that $85.5 \%$ of teacher feedbacks are positive among which positive comment is the most widely used in teacher talk. As for the negative feedback, none of the three teachers use direct negative feedback. From the questionnaire for students, $69 \%$ students state that their teachers always listen carefully with a smile on the face when students answer questions. $47 \%$ students think their teachers often give praise and comments on their answers and responses while $26 \%$ students believe that their teachers always give a very simple positive feedback. Additionally, only $3 \%$ students agree that teachers should interrupt them and correct their mistakes or errors immediately and directly. $93 \%$ students add one of major reasons is that it will make them lose face and discourage them a lot. 
Table 4

Teachers' Feedback

\begin{tabular}{|c|c|c|c|c|c|c|c|c|c|}
\hline \multirow{3}{*}{ Course name } & \multicolumn{4}{|c|}{ Positive feedback } & \multicolumn{4}{|c|}{ Negative feedback } & \multirow{3}{*}{ Total times of feedback } \\
\hline & \multicolumn{2}{|c|}{ Simple } & \multicolumn{2}{|c|}{ Comment } & \multicolumn{2}{|c|}{ Direct } & \multicolumn{2}{|c|}{ Indirect } & \\
\hline & Times & $\%$ & Times & $\%$ & Times & $\%$ & Times & $\%$ & \\
\hline Business English interpreting & 5 & 31.3 & 8 & 50 & 0 & 0 & 3 & 18.8 & 16 \\
\hline Business English translation & 1 & 10 & 7 & 70 & 0 & 0 & 2 & 20 & 10 \\
\hline Business English correspondence & 6 & 28.6 & 14 & 66.7 & 0 & & 1 & 4.8 & 21 \\
\hline Total & 12 & & 29 & & 0 & 0 & 6 & & 47 \\
\hline Mean & 4 & 23.3 & 9.7 & 62.2 & 0 & 0 & 2 & 14.5 & 15.7 \\
\hline
\end{tabular}

\section{Implications for Business English Teachers}

Undoubtedly, some implications for professional development of business English teachers can be drawn from this research. Many researches have proved that teacher talk is conducive to students' second language acquisition. The findings of this paper also find out there are still some problems in the current business English teaching from the perspective of teacher talk.

\section{For the Amount of Teacher Talk Time}

ZHAO Xiao-hong (1998) finds that teacher talk takes up 61\%-90\% of the whole class time in the traditional teacher-centered English teaching classroom. The findings of the research also show that teacher talk dominates (64\%) the business English classroom teaching although there are some differences in different business courses. Seliger (1983) argues that the more participation in classroom interaction, the higher learning score the students will get. Swain (1985) holds that students fail to achieve native speaker competence partly due to few opportunities to speak in class. Allwright (1991) indicates that student talk should be considered and it is inevitable that teacher-centered teaching will surely be replaced by student-centered teaching in class. Therefore, business English teachers should rack their minds to design activities and tasks based on the analysis of students and social needs to the extent that students' interests could be stimulated to participate in the classroom interaction.

\section{For the Use of Native Language}

As for how much Chinese that business English teacher can use in business English teaching, there still exist conflicting ideas among researchers. According to the investigation, too much Chinese will hinder students from developing English thinking mode. Therefore, business English teachers should attach great importance to a good solid foundation of business knowledge so as to reduce their own dependence on Chinese.

\section{For the Quality of Teacher Talk}

Business English, as one of branches of English for Special Purpose, is quite different from college English. Business English teaching not only involves English itself, but also relates to business knowledge as well as intercultural communication. However, $67 \%$ of interviewed teachers in the experiment have never thought about teacher talk and its functions in classroom teaching, let alone how to improve teacher talk. Some teachers state that teacher talk only exists in English knowledge instruction and business background explanations which are greatly in consistent with traditional concept of teacher talk. In the survey, $86 \%$ students think the quality of their teachers' teacher talk in business knowledge should be improved. However, the majority of business English 
teachers switch to business English teaching from linguistics, literature, or translation teaching. Most of them have no solid relative business knowledge or training. Therefore, they usually feel impotent to make a deep interpretation of some professional terms. It is quite urgent for the school to provide funds for business teachers to have short or long-term business training so as to cultivate high quality talents to meet the social needs for business personnel.

\section{For Teacher Feedback}

As one of the important aspects of teacher talk, feedback attracts more and more researchers' attention in recent years. Timely and effective feedback is an important medium for the stimulation of students' interests and confidence in language learning. It is found that more display questions are raised than referential questions. Display questions are better for students' comprehensible input of knowledge while referential questions are found to be beneficial for the interaction between teachers and students. Hence, teachers engaged in business English teaching are suggested to employ more referential questions.

\section{Conclusion}

Nowadays, teacher talk has become one of the focuses in the research of second language acquisition. However, the studies of teacher talk of business English teachers are far from enough. Through the detailed analysis of video records, interview, and questionnaires, the paper points out the problems existing in business English teaching and provides some suggestions for business English teachers. Hopefully, the empirical study on teacher talk of business English teachers can make a small contribution to the future research on teacher talk.

\section{References}

Allwright, D., \& Bailey, K. M. (1991). Focus on the language classroom: An introduction to classroom research for language teachers. Cambridge: Cambridge University Press.

Ellis, R. (1994). The study of second language acquisition. Oxford: Oxford University Press.

HU, Q. Q. (2004). Investigation of questioning mode of college English teachers. Foreign Language World, 6, 22-27.

HU, X. W. (2000). Characteristics and functions of teacher talk. Shangdong Foreign Language Teaching Journal, 3, 39-43.

Nunan, D. (1991). Language teaching methodology: A text book for teachers. Englewood Cliffs, New Jersey: Prentice Hall.

Richards, J. C. (1992). Longman dictionary of language teaching \& applied linguistics. Beijing: Foreign Language Teaching and Research Press.

Seliger, H. W. (1983). Learner interaction in the classroom and its effects on language acquisition. In H. W. Seliger and M. H. Long (Eds.), Classroom oriented research in second language acquisition. Rowley, Mass.: Newbury House.

Sinclair, J., \& Brazil, D. (1982). Teacher talk. Oxford: Oxford University Press.

Swain, M. (1985). Communicative competence: Some roles of comprehensible input and comprehensible output in its development. In S. Gass and C. Madden (Eds.), Input in second language acquisition (pp. 248-249). Rowley, Mass.: Newbury House.

Wright, T. (2005). Classroom management in language education. NY: Palgrave Macmillan.

ZHAO, X. H. (1998). Investigation and analysis of teacher talk in college English reading. Foreign Language World, $2,17-22$.

ZHOU, X., \& ZHOU, Y. (2002). Survey of teacher talk in college English. Foreign Language Teaching and Research, 1, 59-68. 